\title{
4-Chloro-2-toliloamina
}

\section{Metoda oznaczania w powietrzu na stanowiskach pracy z zastosowaniem wysokosprawnej chromatografii cieczowej z detekcją spektrofotometryczną ${ }^{1}$}

\section{4-Chloro-o-toluidine}

\section{Determination in workplace air with high performance liquid chromatography with spectrophotometric detection}

\author{
mgr MARZENA BONCZAROWSKA \\ https://orcid.org/0000-0003-3612-0656 \\ e-mail: Marzena.Bonczarowska@imp.lodz.pl \\ dr SŁAWOMIR BRZEŹNICKI \\ https://orcid.org/0000-0002-0542-8538 \\ Instytut Medycyny Pracy im. prof. dra med. Jerzego Nofera w Łodzi \\ Nofer Institute of Occupational Medicine, Łódź, Poland
}

Numer CAS

$95-69-2$

\section{Streszczenie}

4-Chloro-2-toliloamina (4-CTA) jest ciałem stałym występującym w postaci szaro-białych, krystalicznych płatków. Jest dobrze rozpuszczalna w wodzie i etanolu, natomiast słabo rozpuszczalna w tetrachlorku węgla. Obecnie 4-chloro-2-toliloamina jest stosowana jako barwnik w immunochemii i biologii molekularnej, a także jako jeden z odczynników w kolorymetrycznej metodzie stosowanej do potwierdzania autentyczności leków. Związek może wywoływać takie niepożądane skutki, jak: działanie methemoglobinotwórcze, podrażnienia skóry i oczu, ostre krwotoczne zapalenie pęcherza moczowego. 4-Chloro-2-toliloamina wykazuje działanie mutagenne i genotoksyczne, jest również podejrzewana o działanie rakotwórcze (rak pęcherza moczowego). Celem prac badawczych było opracowanie i walidacja metody oznaczania 4-chloro-2-toliloaminy w powietrzu na stanowiskach pracy. Opracowana metoda oznaczania 4-chloro-2-toliloaminy polega na pochłanianiu tej substancji na filtrze z włókna szklanego (nasączonego kwasem solnym) oraz na żelu krzemionkowym (pokrytym kwasem solnym), ekstrakcji za pomocą metanolu i chromatograficznej analizie otrzymanego roztworu. Do badań wykorzystano chromatograf cieczowy z detektorem spektrofotometycznym (HPLC-UV-VIS), wyposażony w kolumnę Supelco Discovery wypełnioną złożem typu C-18. Opracowana metoda jest liniowa w zakresie stężeń $0,2 \div 4,0 \mu \mathrm{g} / \mathrm{ml}$, co odpowiada zakresowi $0,002 \div 0,04 \mathrm{mg} / \mathrm{m}^{3} \mathrm{dla}$ próbki powietrza o objętości $200 \mathrm{l}$. Opisana metoda analityczna umożliwia oznaczanie 4-chloro-2-toliloaminy w powietrzu na stanowiskach pracy w obecności substancji współwystępujących. Metoda charakteryzuje się dobrą precyzją oraz dokładnością i spełnia wymagania zawarte w normie europejskiej PN-EN 482 dla procedur dotyczących oznaczania czynników chemicznych. Opracowana metoda oznaczania 4-chloro-2-toliloaminy w powietrzu na stanowiskach pracy została zapisana w postaci procedury analitycznej, którą zamieszczono w załączniku. Zakres tematyczny artykułu obejmuje zagadnienia zdrowia oraz bezpieczeństwa i higieny środowiska pracy będące przedmiotem badań z zakresu nauk o zdrowiu oraz inżynierii środowiska.

Słowa kluczowe: 4-chloro-2-toliloamina, metoda analityczna, narażenie zawodowe, wysokosprawna chromatografia cieczowa, nauki o zdrowiu, inżynieria środowiska.

\footnotetext{
${ }^{1}$ Opracowano na podstawie wyników V etapu programu wieloletniego „Poprawa bezpieczeństwa i warunków pracy”, finansowanego w latach 2020-2022 w zakresie badań naukowych i prac rozwojowych przez ministra właściwego ds. nauki/Narodowe Centrum Badań i Rozwoju (projekt nr II.PB.02 pt.: Opracowanie metod oznaczania 12 szkodliwych substancji chemicznych w powietrzu na stanowiskach pracy do oceny narażenia zawodowego).

Koordynator programu: Centralny Instytut Ochrony Pracy - Państwowy Instytut Badawczy.
} 


\section{Abstract}

4-chloro-o-toluidine (4-CTA) at room temperature is a gray to white solid flakes with a weak fishy odor. It is soluble with water or ethanol, slightly soluble in carbon tetrachloride. Currently, it is used as a stain in immunochemistry and molecular biology or as a standard in colorimetric method for medicines identity. 4-CTA can cause many adverse effects like skin or eye irritation, methemoglobinemia and hematuria. 4-CTA indicates mutagenic and genotoxic effects and is suspected to be carcinogenic to humans (bladder cancer). The aim of this study was to develop and validate a method for determining 4-CTA in workplace air. The developed method for determining 4-CTA is based on the collection of 4-CTA on glass fiber filters impregnated with hydrochloric acid connected to sorbent tube filed with two sections of silica gel coated with hydrochloric acid. Filters and sorbent are extracted with methanol and resulted solution is analysed with high performance liquid chromatography with spectrophotometric detection. The study was performed using a liquid chromatograph equipped with Supelco Discovery C-18 column. The developed method is linear in the concentration range of $0.2-4.0 \mu \mathrm{g} / \mathrm{ml}$, which is equivalent to the range of $0.002-0.04 \mathrm{mg} / \mathrm{m}^{3}$ for $200-\mathrm{L}$ air sample. The analytical method described in this paper makes it possible to determine 4-CTA in workplace air in the presence of other substances. The method is precise, accurate and it meets the criteria for procedures for determining chemical agents listed in Standard No. PN-EN 482. The developed method of determining 4-CTA in workplace air has been recorded as an analytical procedure (see Appendix). This article discusses the problems of occupational safety and health, which are covered by health sciences and environmental engineering.

Keywords: 4-chloro-o-toluidine, analytical method, occupational exposure, high performance liquid chromatography, health sciences, environmental engineering.

\section{WPROWADZENIE}

4-Chloro-2-toliloamina (4-CTA) jest ciałem stałym występującym w postaci szaro-białych, krystalicznych płatków. Jest dobrze rozpuszczalna $\mathrm{w}$ wodzie i etanolu, natomiast słabo rozpuszczalna $\mathrm{w}$ tetrachlorku węgla (Kilanowicz i in. 2020; PubChem 2020).

4-Chloro-2-toliloaminę można otrzymać w wyniku reakcji chlorowania: $o$-toluidyny, 2-formylotoluenu albo 2-acetyloaminotoluenu, a następnie otrzymany produkt poddaje się hydrolizie lub alkoholizie (IARC 1990).

W warunkach narażenia zawodowego 4-chloro-2-toliloamina może dostawać się do organizmu drogą inhalacyjną, pokarmową oraz $w$ wyniku bezpośredniego kontaktu ze skórą. Związek ten może wywoływać szereg niepożądanych skutków, np.: działanie methemoglobinotwórcze, podrażnienia skóry i oczu lub ostre krwotoczne zapalenie pęcherza moczowego. 4-Chloro-2-toliloamina jest również podejrzewana o działanie rakotwórcze (rak pęcherza moczowego). Rakotwórcze działanie tego związku zostało potwierdzone badaniami na zwierzętach zarówno w warunkach in vivo, jak i in vitro. 4-Chloro-2-toliloamina wykazuje również działanie mutagenne i genotoksyczne.
Eksperci International Agency for Research on Cancer (IARC) zaliczyli 4-chloro-2-toliloaminę do grupy $2 \mathrm{~A}$, tj. do grupy związków o prawdopodobnym działaniu rakotwórczym na człowieka (IARC 2010). W Unii Europejskiej 4-chloro-2-toliloamina i jej chlorowodorek zostały zaklasyfikowane jako substancje rakotwórcze kategorii zagrożenia 1B (Rozporządzenie... 2008).

W wielu państwach Unii Europejskiej produkcja i stosowanie 4-chloro-2-toliloaminy zostały ograniczone. Wynika to $\mathrm{z}$ obowiązujących przepisów prawnych rozporządzenia REACH. W przeszłości 4-chloro-2-toliloamina była wykorzystywana do produkcji barwników stosowanych w przemyśle tekstylnym i skórzanym oraz do produkcji insektycydów (chlordimeform). Obecnie 4-chloro-2-toliloamina jest stosowana jako barwnik w immunochemii i biologii molekularnej, a także jako jeden $\mathrm{z}$ odczynników w kolorymetrycznej metodzie stosowanej do potwierdzania autentyczności leków (IARC 2010; PubChem 2020). Zawodowe narażenie na 4-chloro-2-toliloaminę może występować podczas produkcji, przetwarzania oraz stosowania tego związku w czasie prac laboratoryjnych. 
Klasyfikację oraz oznakowanie 4-chloro-2-toliloaminy i jej chlorowodorku, zgodnie z tabelą 3.1. załącznika VI do rozporządzenia Parlamentu Europejskiego i Rady (WE) nr 1272/2008 z dnia 16 grudnia 2008 r. w sprawie klasyfikacji, oznakowania i pakowania substancji i mieszanin, zmieniającego i uchylającego dyrektywy 67/548/EWG i 1999/45/WE oraz zmieniającego rozporządzenie (WE) nr 1907/2006, zwanego rozporządzeniem CLP (Dz. Urz. UE z dnia 31.12.2008 r.), przedstawiono w tabeli 1.

Zespół Ekspertów ds. Czynników Chemicznych Międzyresortowej Komisji do spraw Najwyższych Dopuszczalnych Stężeń i Natężeń Czynników Szkodliwych dla Zdrowia w Środowisku Pracy zaproponował przyjęcie wartości najwyższego dopuszczalnego stężenia (NDS) dla frakcji wdychalnej 4-chloro-2-toliloaminy na poziomie $0,02 \mathrm{mg} / \mathrm{m}^{3}$, stwierdzając jednocześnie, że nie ma merytorycznych podstaw do ustalenia wartości najwyższego dopuszczalnego stężenia chwilowego (NDSCh) i dopuszczalnego stężenia w materiale biologicznym (DSB), (Kilanowicz i in. 2020). Wartość NDS dla 4-chloro-2-toliloaminy i jej chlorowodorku została zamieszczona w rozporządzeniu Ministra Rozwoju, Pracy i Technologii w sprawie najwyższych dopuszczalnych stężeń i natężeń czynników szkodliwych dla zdrowia w środowisku pracy $z$ dnia 18 lutego $2021 \mathrm{r}$.

Celem pracy było opracowanie odpowiednio czułej i selektywnej metody oznaczania frakcji wdychalnej 4-chloro-2-toliloaminy w powietrzu na stanowiskach pracy, umożliwiającej dokonanie oceny narażenia zawodowego.

Zakres tematyczny artykułu obejmuje zagadnienia zdrowia oraz bezpieczeństwa i higieny środowiska pracy będące przedmiotem badań z zakresu nauk o zdrowiu oraz inżynierii środowiska.

Tabela 1. Klasyfikacja 4-chloro-2-toliloaminy i jej chlorowodorku zgodnie z obowiązującymi aktami prawnymi (rozporządzenie Parlamentu Europejskiego i Rady (WE) nr 1272/2008)

Table 1. Classification and labeling of 4-chloro-o-toluidine in accordance with the applicable legal acts (Regulation (EC) No 1272/2008)

\begin{tabular}{|l|l|}
\hline Klasyfikacja zagrożenia i kody kategorii & Kody zwrotów wskazujących rodzaj zagrożenia \\
\hline Carc. 1B - rakotwórczość, kategoria zagrożenia 1B & H350 - może powodować raka \\
Muta. 2 - mutagenność, kategoria zagrożenia 2 & H341 - podejrzewa się, że powoduje wady genetyczne \\
Acute Tox. 3* - toksyczność ostra (po narażeniu drogą inhalacyjną, & H331 - działa toksycznie w następstwie wdychania \\
w kontakcie ze skórą i po połknięciu), kategoria zagrożenia 3* & H311 - działa toksycznie w kontakcie ze skórą \\
& H301 - działa toksycznie po połknięciu \\
Aquatic Acute 1 - zagrożenie dla środowiska wodnego & H400 - działa bardzo toksycznie na organizmy wodne \\
(zagrożenie ostre), kategoria zagrożenia 1 & H411 - działa toksycznie na organizmy wodne, powodując \\
Aquatic Chronic 1 - zagrożenie dla środowiska wodnego & długotrwałe skutki \\
\hline (zagrożenie przewlekłe), kategoria zagrożenia 1 &
\end{tabular}

Objaśnienie: $\left({ }^{*}\right)$ - minimum klasyfikacji.

\section{CZĘŚĆ DOŚWIADCZALNA}

\section{Aparatura analityczna}

Do badań wykorzystano chromatograf cieczowy firmy Waters Acquity Arc LC System, wyposażony w: poczwórny system pomp wysokociśnieniowych, detektor spektrofotometryczny Waters 2489, termostat kolumny analitycznej, automatyczny dozownik próbek i komputer z programem sterowania i akwizycji danych. Analizy chromatograficznej dokonywano na kolumnie analitycznej Supelco Discovery o wymiarach $150 \times 2,1 \mathrm{~mm}$, o średnicy ziaren $5 \mu \mathrm{m}$, wypełnionej żelem krzemionkowym modyfikowanym łańcuchami węglowymi (C-18). Do pobierania próbek powietrza stosowano aspiratory indywidualne GilAir 3. Substancje wzorcowe odważano, stosując wagę analityczną Sartorius Research, a do ekstrakcji próbek wykorzystano mieszadło rolkowe. 


\section{Materiały}

Wszystkie badania wykonano $\mathrm{z}$ zastosowaniem następujących materiałów:

- filtry z włókna szklanego GF/A o średnicy $25 \mathrm{~mm}$ (Whatman),

- rurki sorpcyjne z żelem krzemionkowym (75/150 mg),

- filtry strzykawkowe z membraną z PTFE (Supelco),

- kolby miarowe o pojemności: 1; 5 i $250 \mathrm{ml}$,

- naczynka (wialki) szklane o pojemności 2 i $4 \mathrm{ml}$ ze szkła oranżowego,
- pipety automatyczne nastawne o pojemności: $0,010 \div 0,1 ; 0,1 \div 1$ i $0,5 \div 5 \mathrm{ml}$.

\section{Odczynniki}

Wszystkie badania wykonano $\mathrm{z}$ zastosowaniem następujących odczynników:

- 4-chloro-2-toliloamina (Merck),

- metanol do HPLC (JT Baker),

- woda o czystości do HPLC,

- kwas solny stężony (POCh).

\section{WYNIKI BADAŃ I ICH OMÓWIENIE}

W dostępnej literaturze nie znaleziono wyników badań dotyczących oznaczania 4-chloro-2-toliloaminy (4-CTA) w powietrzu na stanowiskach pracy. $\mathrm{W}$ analizie amin aromatycznych oraz chlorowanych amin aromatycznych $\mathrm{w}$ różnych mediach (wyroby tekstylne, skórzane, woda, materiał biologiczny, żywność) są stosowane głównie takie techniki chromatograficzne, jak chromatografia gazowa (Birner, Neuman 1988; Chormeya i in. 2020; Nervekar i in. 2002; NIOSH 1994; OSHA 1988; Otero i in. 2017; Riffelmann i in. 1995) lub wysokosprawna chromatografia cieczowa (Coquart, Hennion 1993; Dall'Anese i in. 2014; HSE 2014; Riffelmann i in. 1995; Wollseifen 2019).

Dane literaturowe wskazują, że 4-chloro-2-toliloaminy w postaci pochodnych można oznaczać techniką wysokosprawnej chromatografii cieczowej przy zastosowaniu kolumn analitycznych wypełnionych fazą oktadecylową C-18 (Coquart, Hennion 1993; Dall'Anese i in. 2014; HSE 2014; Wollseifen 2019), z których substancje są eluowane mieszaninami metanolu bądź acetonitrylu i roztworów buforowych (techniki LC-UV-VIS i EC) lub z dodatkiem kwasu mrówkowego (technika LC-MS/MS). Zastosowanie kolumn analitycznych wypełnionych złożem C-18 i odpowiedni dobór rozpuszczalników umożliwiają rozdzielenie i selektywne oznaczenie amin aromatycznych oraz ich alkilowych i chlorowych pochodnych (w tym 4-chloro-2-toliloaminy) w wieloskładnikowych mieszaninach tych związków (Wollseifen 2019).

Podczas prac nad opracowaniem metody oznaczania 4-chloro-2-toliloaminy zastosowa- no dwie kolumny analityczne: kolumnę Waters CORTEX C-18 o długości $150 \mathrm{~mm}$, średnicy wewnętrznej $3 \mathrm{~mm}$ i średnicy ziaren wypełnienia $2,7 \mu \mathrm{m}$ oraz kolumnę Supelco Discovery o długości $150 \mathrm{~mm}$, średnicy wewnętrznej 2,1 mm i średnicy ziaren wypełnienia $5 \mu \mathrm{m}$. Z uwagi na duże opory przepływu przez kolumnę wypełnioną złożem o średnicy $<3 \mu \mathrm{m}$ zdecydowano o zastosowaniu w dalszych pracach kolumny firmy Supelco. Jako fazę ruchomą zastosowano mieszaninę metanolu i wody o zmiennym ( $w$ trakcie trwania analizy) składzie procentowym (elucja gradientowa). Długość fali analitycznej $\lambda=240 \mathrm{~nm}$ dobrano na podstawie danych literaturowych (Coquart, Hennion 1993; Wollseifen 2019). Wszystkie dane dotyczące parametrów pracy chromatografu cieczowego przedstawiono w tabeli 2 .

Zastosowane $\mathrm{w}$ analizie warunki pracy chromatografu cieczowego $\mathrm{z}$ detektorem UV-VIS (tab. 2.) umożliwiają selektywne oznaczenie tego związku w przypadku obecności w badanej próbce innych amin aromatycznych. Na rycinie 1. przedstawiono chromatogram mieszaniny: $o$-anizydyny, $m$-toluidyny oraz 4-chloro-2-toliloaminy. Należy pamiętać, iż zastosowane parametry oznaczania 4-chloro-2-toliloaminy są parametrami przykładowymi i można je modyfikować (skład fazy ruchomej) pod kątem obecności substancji mogących współwystępować $\mathrm{w}$ danym środowisku pracy. 
Tabela 2. Warunki pracy chromatografu cieczowego z detektorem UV-VIS

Table 2. Working conditions of a liquid chromatograph with a UV-VIS detector

\begin{tabular}{|c|c|c|c|}
\hline \multicolumn{4}{|c|}{ Kolumna analityczna Supelco Discovery C-18 150 x 2,1 mm, 5 m } \\
\hline $\begin{array}{l}\text { Faza ruchoma } \\
\text { Program - gradient }(v \cdot v)\end{array}$ & $\begin{array}{l}0 \mathrm{~min} \\
1 \\
6 \\
7 \\
13\end{array}$ & $\begin{array}{l}80 \\
80 \\
20 \\
80 \\
80\end{array}$ & $\begin{array}{c}\text { metanol (B) } \\
20 \\
20 \\
80 \\
20 \\
20\end{array}$ \\
\hline \multicolumn{4}{|c|}{$0,4 \mathrm{ml} / \mathrm{min}$} \\
\hline Temperatura kolumny & \multicolumn{2}{|c|}{$30^{\circ} \mathrm{C}$} & \\
\hline Długość fali analitycznej & \multicolumn{2}{|c|}{$\lambda=240 \mathrm{~nm}$} & \\
\hline Objętość próbki & \multicolumn{2}{|c|}{$5 \mu l$} & \\
\hline
\end{tabular}

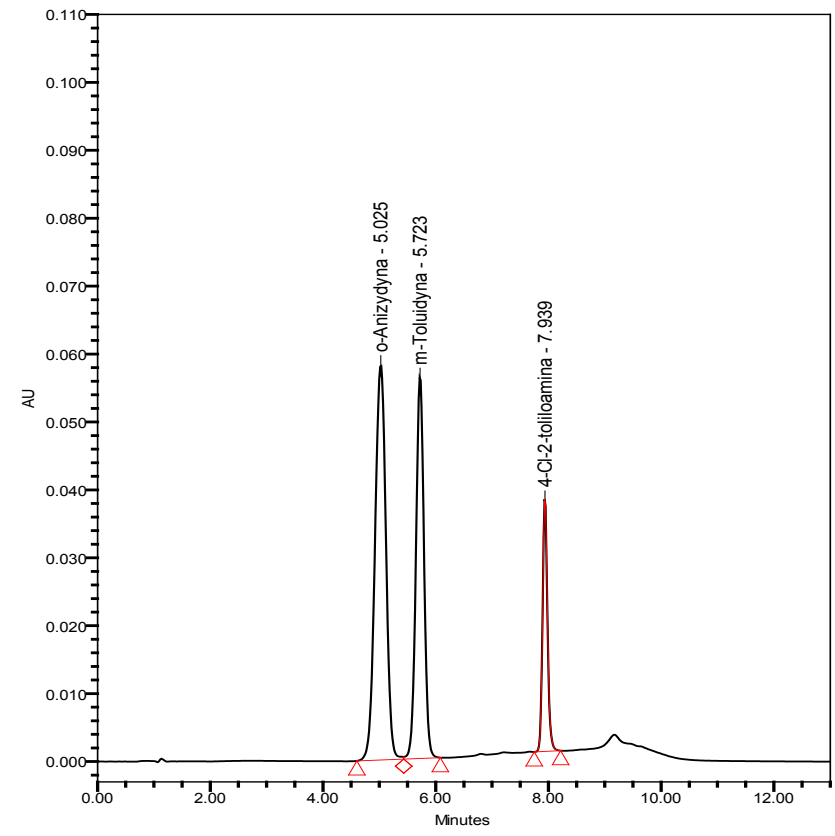

Ryc. 1. Chromatogram mieszaniny o-anizydyny, $m$-toluidyny i 4-chloro-2-toliloaminy. Kolumna Supelco Discovery (150 x 2,1 mm), długość fali analitycznej $\lambda=240 \mathrm{~nm}$

Fig. 1. Chromatogram of a mixture of $o$-anisidine, $m$-toluidine and 4-chloro-o-toluidine. Supelco Discovery column $(150 \times 2.1 \mathrm{~mm})$, analytical wavelength $\lambda=240 \mathrm{~nm}$

\section{Pobieranie i przygotowanie próbek do analizy}

W dostępnej literaturze nie znaleziono publikacji dotyczących oznaczania 4-chloro-2-toliloaminy w powietrzu. Opisane metodyki oznaczania amin aromatycznych lub chlorowanych amin aromatycznych zakładają stosowanie do pobierania próbek filtrów nasączonych roztworem kwasu siarkowego (Jeżewska i in. 2011) oraz (opcjonalnie) rurek sorpcyjnych wypełnionych Tenaxem (HSE 2014). Metodyka oznaczania 4-chloro-2-toliloaminy w powietrzu zalecana przez Occupational Safety and Health Administration (OSHA) zakłada stosowanie rurek sorpcyjnych wypełnionych dwoma warstwami żelu krzemionkowego (OSHA 1988). Zastosowanie podobnego medium pochłaniającego (żel krzemionkowy) zakłada metoda oznaczania amin aromatycznych $w$ powietrzu zaproponowana przez National Institute of Occupational Safety and Health (NIOSH 1994). Z kolei metodyka oznaczania 4-chloro-2-toliloaminy zalecana przez Federation of the Employment Accidents Insurance Institutions of Germany zakłada wykorzystanie do tego celu żelu krzemionkowego pokrytego kwasem solnym (FEAIIG 1993).

Z uwagi na możliwość występowania 4-chloro-2-toliloaminy w badanym powietrzu również w postaci chlorowodorku zdecydowano o zastosowaniu 
do pobierania próbek powietrza zestawu złożonego z filtra $\mathrm{z}$ włókna szklanego nasączonego kwasem solnym oraz rurki sorpcyjnej wypełnionej żelem krzemionkowym pokrytym kwasem solnym.

Wprowadzona rozporządzeniem Ministra Rozwoju, Pracy i Technologii (Rozporządzenie... 2021) wartość NDS dla 4-chloro-2-toliloaminy $\left(0,02 \mathrm{mg} / \mathrm{m}^{3}\right)$ obliguje do oznaczania stężeń tego związku we frakcji wdychalnej. Próbki powietrza do oznaczania 4-chloro-2-toliloaminy zgodnie $\mathrm{z}$ zasadami podanymi w normie PN-Z-04008-7:2002/Az1:2004 należy pobierać za pomocą aspiratorów indywidualnych umożliwiających pobieranie powietrza ze strumieniem objętości 2 l/min i wyposażonych w głowice do pobierania frakcji wdychalnej.

W celu zbadania wpływu założonych warunków pobierania próbek powietrza na retencję 4-chloro-2-toliloaminy na filtrach z włókna szklanego i żelu krzemionkowym przygotowano trzy serie po sześć filtrów nasączonych roztworem kwasu solnego o stężeniu $0,2 \mathrm{~mol} / \mathrm{l}$, połączonych z rurkami sorpcyjnymi wypełnionymi dwoma warstwami (150 i $75 \mathrm{mg}$ ) żelu krzemionkowego pokrytego kwasem solnym o takim samym stężeniu. Na dłuższą warstwę żelu naniesiono po $10 \mu \mathrm{l}$ roztworów wzorcowych 4-chloro-2-toliloaminy o stężeniach: 40; 200 i $800 \mu \mathrm{g} / \mathrm{ml}$. Przez zestaw przepuszczono za pomocą średnioprzepływowych aspiratorów indywidualnych 2001 powietrza ze stałym strumieniem objętości $21 / \mathrm{min}$. Po tym czasie filtry wraz $\mathrm{z}$ żelem krzemionkowym z dłuższej warstwy przeniesiono do naczynek szklanych o pojemności $4 \mathrm{ml}$ i poddano 30-minutowej ekstrakcji za pomocą $2 \mathrm{ml}$ metanolu oraz mieszadła rolkowego. Takiej samej procedurze poddano żel krzemionkowy z krótszej warstwy. Ekstrakty przesączono przez filtry strzykawkowe z PTFE o średnicy porów $0,45 \mu \mathrm{m}$, a następnie poddano analizie chromatograficznej w ustalonych wcześniej warunkach. Wartości pól powierzchni pików badanego związku uzyskane $\mathrm{z}$ analiz ekstraktów porównano $\mathrm{z}$ wynikami analiz ekstraktów z filtrów i żelu krzemionkowego, na które naniesiono roztwory wzorcowe o takich samych stężeniach 4-chloro-2-toliloaminy i przez które nie przepuszczano powietrza.

Wyniki badań dotyczących warunków pobierania próbek powietrza przedstawiono w tabeli 3.

Tabela 3. Badanie warunków pobierania próbek powietrza do oznaczeń 4-chloro-2-toliloaminy

Table 3. Examination of the air sampling conditions for the determination of 4-chloro- 0 -toluidine

\begin{tabular}{|c|c|c|c|c|c|}
\hline \multirow{2}{*}{$\begin{array}{l}\text { Medium } \\
\text { pochłaniające }\end{array}$} & \multirow{2}{*}{$\begin{array}{l}\text { Zawartość } \\
\text { 4-CTA na żelu, } \\
\mu \mathrm{g}\end{array}$} & \multicolumn{2}{|c|}{ Pole powierzchni piku } & \multirow{2}{*}{$\begin{array}{l}\text { Współczynnik } \\
\text { odzysku }\end{array}$} & \multirow{2}{*}{$\begin{array}{c}\text { Średnia wartość } \\
\text { współczynnika odzysku }\end{array}$} \\
\hline & & $\begin{array}{l}\text { roztwór } \\
\text { kontrolny }\end{array}$ & ekstrakt & & \\
\hline \multirow[t]{3}{*}{$\begin{array}{l}\text { Żel krzemionkowy } \\
\text { pokryty } \\
0,2 \text { bmol/l HCl } \\
\text { i filtr z włókna } \\
\text { szklanego }\end{array}$} & 0,4 & $\begin{array}{l}13055 \\
13195 \\
13292\end{array}$ & $\begin{array}{l}11939 \\
11676 \\
11586 \\
12155 \\
11803 \\
11838\end{array}$ & $\begin{array}{l}0,91 \\
0,89 \\
0,88 \\
0,92 \\
0,90 \\
0,90 \\
0,01 \\
1,6 \% \\
\end{array}$ & 0,90 \\
\hline & 2,0 & $\begin{array}{l}68432 \\
68324 \\
69339\end{array}$ & $\begin{array}{l}61831 \\
60679 \\
68517 \\
59594 \\
57003 \\
62811\end{array}$ & $\begin{array}{l}0,90 \\
0,88 \\
1,00 \\
0,87 \\
0,83 \\
0,91 \\
0,06 \\
6,4 \%\end{array}$ & 0,90 \\
\hline & 8,0 & $\begin{array}{l}230529 \\
265903 \\
253627\end{array}$ & $\begin{array}{l}240935 \\
222462 \\
219418 \\
212908 \\
230936 \\
210782\end{array}$ & $\begin{array}{l}0,96 \\
0,90 \\
0,88 \\
0,85 \\
0,92 \\
0,84 \\
0,05 \\
5,0 \%\end{array}$ & 0,89 \\
\hline \multicolumn{3}{|c|}{$\begin{array}{l}\text { Średni współczynnik odzysku, Śr, \% } \\
\text { Odchylenie standardowe, SD } \\
\text { Współczynnik zmienności, CV, \% }\end{array}$} & \multicolumn{3}{|l|}{$\begin{array}{l}0,90 \\
0,04 \\
4,50\end{array}$} \\
\hline
\end{tabular}


Analiza tych danych wskazuje, że przyjęty sposób pobierania próbek powietrza nie powoduje powstawania istotnych strat oznaczanego związku. Średnie wartości współczynnika odzysku 4-chloro-2-toliloaminy z filtrów i żelu krzemionkowego (nasączonych/pokrytych kwasem solnym), przez które przepuszczono próbkę powietrza o objętości $200 \mathrm{l}$, dla trzech analizowanych zawartości 4-chloro-2-toliloaminy na żelu $(0,4 ; 2$ i $8 \mu \mathrm{g})$ wynoszą odpowiednio: 0,90 (SD - 0,01); 0,90 (SD - 0,06) i 0,89 (SD - 0,05). Średnia (dla trzech stężeń) wartość współczynnika odzysku wynosi 0,90 (SD - 4,03). W żadnej z badanych próbek nie stwierdzono obecności 4-chloro-2-toliloaminy w drugiej warstwie żelu.

\section{Badanie zakresu stosowania i precyzji metody analitycznej}

W celu określenia zakresu roboczego metody oznaczania 4-chloro-2-toliloaminy przygotowano trzy serie po osiem zestawów składających się z filtrów z włókna szklanego i żelu krzemionkowego (nasączonych/pokrytych roztworem kwasu solnego o stężeniu $0,2 \mathrm{~mol} / \mathrm{l})$.

$\mathrm{Na}$ żel krzemionkowy naniesiono po $10 \mu \mathrm{l} \mathrm{roz-}$ tworów wzorcowych 4-chloro-2-toliloaminy o stężeniach: $0 ; 40 ; 80 ; 100 ; 200 ; 400 ; 600$ i $800 \mu \mathrm{g} / \mathrm{ml}$, co odpowiada zawartości badanego związku na żelu: $0 ; 0,4 ; 0,8 ; 1,0 ; 2,0 ; 4,0 ; 6,0$ i $8,0 \mu$ g. Po odparowaniu rozpuszczalnika filtry i żel umieszczano w naczynkach o pojemności $4 \mathrm{ml}$, dodawano po $2 \mathrm{ml}$ metanolu, a nastepnie poddano ekstrakcji za pomocą mieszadła rolkowego przez $30 \mathrm{~min}$. Uzyskane ekstrakty przepuszczano przez filtry strzykawkowe $\mathrm{z}$ membraną z PTFE o średnicy porów $0,45 \mu \mathrm{m}$, a następnie poddano analizie chromatograficznej.

Wyniki badania liniowości metody (w badanym zakresie stężeń) przedstawiono $\mathrm{w}$ tabeli 4 . oraz graficznie na rycinie 2 .

Tabela 4. Wyniki wzorcowania 4-chloro-2-toliloaminy na żelu krzemionkowym pokrytym 0,2 mol/l kwasem solnym

Table 4. Calibration results of 4-chloro-o-toluidine on silica gel coated with $0.2 \mathrm{~mol} / \mathrm{I}$ hydrochloric acid

\begin{tabular}{|l|c|c|c|c|c|c|c|}
\hline \multirow{2}{*}{ Badane parametry } & \multicolumn{7}{|c|}{ Stężenie, $\mu \mathrm{g} / \mathrm{ml}$} \\
\cline { 2 - 8 } & 0,2 & 0,4 & 0,5 & 1,0 & 2,0 & 3,0 & 4,0 \\
\hline Pole powierzchni piku & 13125 & 24836 & 31926 & 65825 & 127396 & 198304 & 254637 \\
(PPP) & 13822 & 24675 & 32173 & 62851 & 130057 & 192832 & 251625 \\
& 13466 & 24569 & 32445 & 66690 & 127283 & 191035 & 258940 \\
Średnia PPP & 13471,0 & 24693,3 & 32181,3 & 65122,0 & 128245,3 & 194057,0 & 255067,3 \\
Odchylenie & 348,53 & 134,44 & 259,60 & 2013,74 & 1569,97 & 3786,17 & 3676,44 \\
standardowe, SD & & & & & & & 1,95 \\
Współczynnik & 2,59 & 0,54 & 0,81 & 3,09 & 1,22 & & 1,44 \\
zmienności, CV, \% & & & & & & & \\
\hline
\end{tabular}

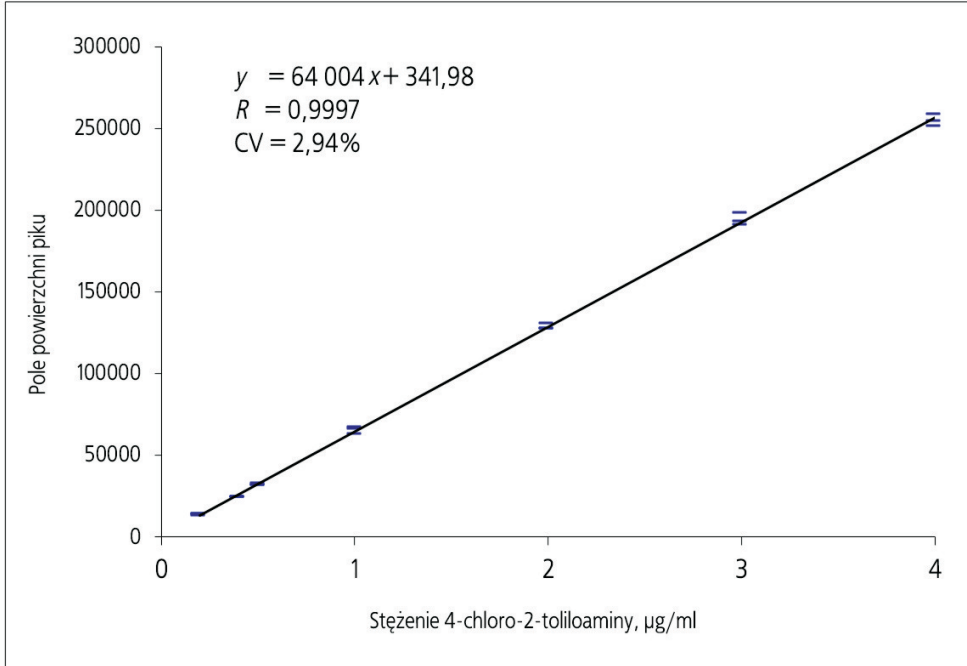

Ryc. 2. Krzywa wzorcowa 4-chloro-2-toliloaminy w zakresie $0,2 \div 4 \mu \mathrm{g} / \mathrm{ml}$

Fig. 2. Standard curve of 4 -chloro-o-toluidine in the range of $0.2 \div 4 \mu \mathrm{g} / \mathrm{ml}$ 
Z przedstawionych danych wynika, iż zależność odpowiedzi detektora spektrofotometrycznego od stężenia 4-chloro-2-toliloaminy ma charakter liniowy w zakresie $0,2 \div 4 \mu \mathrm{g} / \mathrm{ml}$. Zależność tę opisuje równanie $y=64004 x+341,98$. Wyrażony w procentach współczynnik zmienności (CV) dla trzech serii kalibracyjnych wynosi 2,94\%, a współczynnik regresji $r=0,9997$.

W celu zbadania zgodności wyników przy wielokrotnym powtarzaniu oznaczenia przygotowano trzy serie po dziesięć naczynek o pojemności $4 \mathrm{ml}$, do których odmierzono po $150 \mathrm{mg}$ żelu krzemionkowego pokrytego kwasem solnym $(0,2 \mathrm{~mol} / \mathrm{l})$, a następnie na żel $(n=10)$ naniesiono po $10 \mu \mathrm{l}$ roztworów wzorcowych 4-chloro-2-toliloaminy o stężeniach: 40; 200 i $800 \mu \mathrm{g} / \mathrm{ml}$. Po odparowaniu rozpuszczalnika do naczynek dodano po $2 \mathrm{ml}$ metanolu i każdą próbkę poddano ekstrakcji za pomocą mieszadła rolkowego. Ekstrakty po przesączeniu poddano analizie chromatograficznej.

Wyniki badania precyzji metody oznaczania 4-chloro-2-toliloaminy z zastosowaniem techniki LC-UV-VIS przedstawiono w tabeli 5. Współczynniki zmienności (CV) rozrzutów uzyskanych wyników w stosunku do wartości średnich dla stężeń: 0,$2 ; 1,0$ i $4 \mu \mathrm{g} / \mathrm{ml}$ wynoszą odpowiednio: 4,$23 ; 3,9$ i $6,1 \%$. Średnia (dla trzech stężeń) wartość współczynnika zmienności (CV) wynosi $4,9 \%$.

\section{Badanie warunków przechowywania pobranych próbek}

W celu zbadania trwałości 4-chloro-2-toliloaminy przygotowano trzy serie po osiemnaście zestawów składających się z filtra $\mathrm{z}$ włókna szklanego i żelu krzemionkowego, pokrytych roztworem kwasu solnego. Na pierwszą warstwę żelu (150 mg) naniesiono po $10 \mu \mathrm{l}$ roztworów wzorcowych o stężeniach: 40; 200 i $800 \mu \mathrm{g} / \mathrm{ml}$. Po odparowaniu rozpuszczalnika filtry i pierwszą warstwę żelu przeniesiono do naczynek o pojemności $4 \mathrm{ml}$, naczynka szczelnie zamknięto i ptrzechowywano w chłodziarce. Po: 3; 7 i 20 dniach przechowywania poddawano ekstrakcji po sześć próbek $\mathrm{z}$ każdego stężenia. Ekstrakty przepuszczono przez filtry strzykawkowe $\mathrm{z}$ membraną z PTFE o średnicy porów $0,45 \mu \mathrm{m}$, a następnie poddawano analizie chromatograficznej. Uzyskane wartości pól powierzchni pików badanego związku porównano do wyników analiz ekstraktów filtrów przygotowanych w dniu badania.

Wyniki badań warunków do przechowywania próbek przestawiono na rycinie 3.

Wyrażone w procentach średnie wartości wydajności ekstrakcji 4-chloro-2-toliloaminy dla próbek: 0,4; 2 i $8 \mu \mathrm{g} /$ żel po 20 dniach przechowywania wynoszą: 103 (SD - 2,8); 94 (SD - 1,6) i 101\% (SD - 1,7). Średnia (dla trzech stężeń) wartość wydajności ekstrakcji wynosi 99\% (SD - 4,3).

Tabela 5. Wyniki badania precyzji metody oznaczania 4-chloro-2-toliloaminy

Table 5. Results of precision test for determining 4-chloro-o-toluidine

\begin{tabular}{|c|c|c|c|c|c|c|}
\hline Numer analizy & $\begin{array}{c}\text { Stężenie } \\
\text { naniesione } \\
\text { na żel, } \\
\mu \mathrm{g} / \mathrm{ml}\end{array}$ & $\begin{array}{c}\text { Stężenie } \\
\text { oznaczone } \\
\text { w ekstraktach, } \\
\mu \mathrm{g} / \mathrm{ml}\end{array}$ & $\begin{array}{c}\text { Stężenie } \\
\text { naniesione na żel, } \\
\mu \mathrm{g} / \mathrm{ml}\end{array}$ & $\begin{array}{c}\text { Stężenie } \\
\text { oznaczone } \\
\text { w ekstraktach, } \\
\mu \mathrm{g} / \mathrm{ml},\end{array}$ & $\begin{array}{c}\text { Stężenie } \\
\text { naniesione } \\
\text { na żel, } \\
\mu \mathrm{g} / \mathrm{ml}\end{array}$ & $\begin{array}{c}\text { Stężenie } \\
\text { oznaczone } \\
\text { w ekstraktach, } \\
\mu \mathrm{g} / \mathrm{ml}\end{array}$ \\
\hline $\begin{array}{l}1 \\
2 \\
3 \\
4 \\
4 \\
6 \\
7 \\
8 \\
9 \\
10\end{array}$ & 0,2 & $\begin{array}{l}0,200 \\
0,184 \\
0,194 \\
0,193 \\
0,202 \\
0,212 \\
0,207 \\
0,204 \\
0,207 \\
0,194\end{array}$ & 1,0 & $\begin{array}{l}0,997 \\
1,020 \\
0,956 \\
1,003 \\
1,000 \\
1,025 \\
1,004 \\
1,004 \\
0,898 \\
0,959\end{array}$ & 4,0 & $\begin{array}{l}3,583 \\
3,622 \\
3,665 \\
3,643 \\
3,735 \\
3,909 \\
4,299 \\
3,953 \\
3,925 \\
4,098\end{array}$ \\
\hline $\begin{array}{l}\text { Średnia } \\
\text { SD } \\
C V, \%\end{array}$ & \multicolumn{2}{|c|}{$\begin{array}{c}0,200 \\
0,008 \\
4,23\end{array}$} & \multicolumn{2}{|c|}{$\begin{array}{c}0,987 \\
0,038 \\
3,90\end{array}$} & \multicolumn{2}{|c|}{$\begin{array}{c}3,843 \\
0,234 \\
6,10\end{array}$} \\
\hline
\end{tabular}




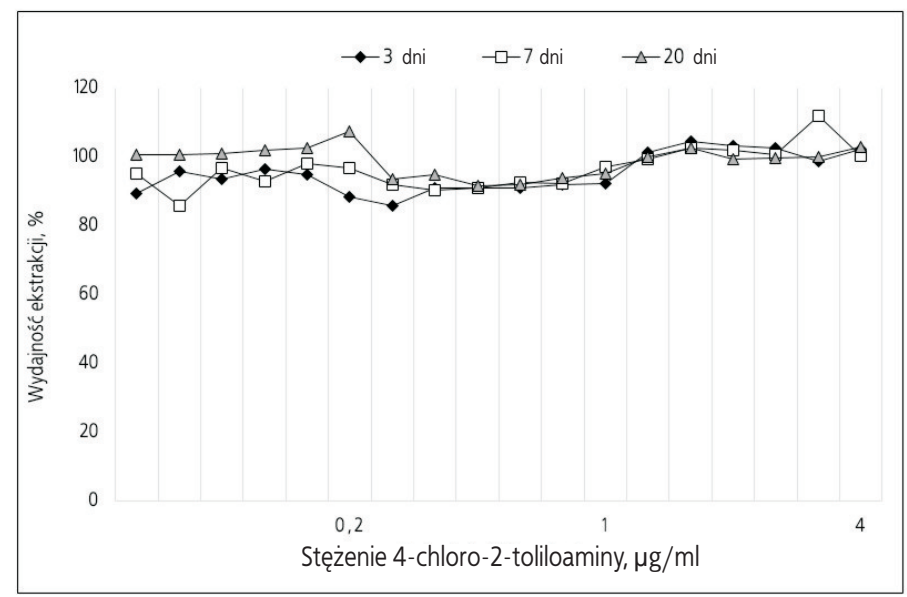

Ryc. 3. Trwałość próbek 4-chloro-2-toliloaminy pobranych na żel krzemionkowy pokryty kwasem solnym w zależności od czasu przechowywania

Fig. 3. Stability of 4-chloro-o-toluidine samples taken on silica gel coated with hydrochloric acid depending on storage time

\section{Walidacja metody}

Walidację metody przeprowadzono zgodnie $\mathrm{z}$ wymaganiami zawartymi w normie europejskiej PN-EN 482.

$\mathrm{Na}$ podstawie przeprowadzonych badań uzyskano następujące dane walidacyjne:

- granica wykrywalności $0,0064 \mu \mathrm{g} / \mathrm{ml}$ $(6,4 \mathrm{ng} / \mathrm{ml})$
- granica oznaczalności

- zakres pomiarowy $(21,3 \mathrm{ng} / \mathrm{ml})$

- współczynnik korelacji charakteryzujący liniowość krzywej wzorcowej $\quad r=0,9997$

- niepewność rozszerzona metody
$0,002 \div$ $0,04 \mathrm{mg} / \mathrm{m}^{3}$

$24 \%$.

\section{PODSUMOWANIE}

$\mathrm{Na}$ podstawie przeprowadzonych badań zaproponowano metodę oznaczania 4-chloro-2-toliloaminy $\mathrm{w}$ powietrzu środowiska pracy $\mathrm{z}$ wykorzystaniem techniki wysokosprawnej chromatografii cieczowej z detekcją spektrofotometryczną. Zastosowanie kolumny analitycznej Supelco Discovery C-18 o wymiarach $150 \times 2,1 \mathrm{~mm}, 5 \mu \mathrm{m}$, pozwala na oznaczenie tego związku w obecności innych amin aromatycznych.

Opisana metoda umożliwia oznaczanie stężeń 4-chloro-2-toliloaminy $\mathrm{w}$ powietrzu środowi- ska pracy w zakresie $0,002 \div 0,04 \mathrm{mg} / \mathrm{m}^{3}$, tj. $1 / 10 \div$ 2 wartości NDS. Metoda została poddana walidacji zgodnie $\mathrm{z}$ wymaganiami zawartymi w normie europejskiej PN-EN 482. Opracowaną metodę oznaczania 4-chloro-2-toliloaminy w powietrzu na stanowiskach pracy zapisano $\mathrm{w}$ formie procedury analitycznej, którą zamieszczono w załączniku.

\section{PIŚMIENNICTWO}

Birner G., Neuman H.G. (1988). Biomonitoring of aromatic amines II: Hemoglobin binding of some monocyclic aromatic amines. Arch. Toxicol. 62, 110-115.

Coquart V., Hennion M.C. (1993). Trace-level monitoring of chloroanilines in environmental waters using on-line trace- enrichment and liquid chromatography with UV and electrochemical detection. Chromatographia 37, 392-398.

Chormeya D.S., Zamana B.T., Maltepea E., Buyukpinara C., Bulgurcuoglub A.E., Turaka F., Erulasc F.A., Bakirdere S. (2020). Simultaneous determination of harmful aromatic 
amine products of azo dyes by gas chromatography-mass spectrometry. J. Anal. Chem. 75, 10, 1330-1334.

Dall'Anese R.G., Bartolini G., Franchi A. (2014). Quantitative determination of 26 aromatic amines derived from banned azo dyes in textiles through the use of LC, tandem MS, and identification of some structural isomers. Agilent Technologies, Application Note [https://www.agilent.com/cs/library/ applications/5991-5169EN.pdf ].

FEAIIG, Federation of the Employment Accidents Insurance Instituons of Germany (1993). Air monitoring methods vol. 4. Method for the determination of $p$-chloroaniline [https:// onlinelibrary.wiley.com/doi/pdf/10.1002/3527600418. am10647e0004].

HSE, Health and Safety Executive (2014). Methods for the determination of hazardous substances. MDHS 75/2. Aromatic amines in air and on surfaces [https://www.hse.gov.uk/ pubns/mdhs/pdfs/mdhs75-2.pdf ].

IARC, International Agency for Research on Cancer (1990). Some flame retardants and textile chemicals, and exposures in the textile manufacturing industry. IARC Monographs on the Evaluation of Carcinogenic Risk to Humans, vol. 48, 123139 [https://publications.iarc.fr/Book-And-Report-Series/ Iarc-Monographs-On-The-Identification-Of-CarcinogenicHazards-To-Humans/Some-Flame-Retardants-And-TextileChemicals-And-Exposures-In-The-Textile-ManufacturingIndustry].

IARC, International Agency for Research on Cancer (2010). Some aromatic amines, organic dyes and related exposures. IARC, Monographs on the Evaluation of Carcinogenic Risk to Humans, vol. 99, 471-498 [https://publications.iarc. fr/Book-And-Report-Series/Iarc-Monographs-On-TheIdentification-Of-Carcinogenic-Hazards-To-Humans/SomeAromatic-Amines-Organic-Dyes-And-Related-Exposures].

Jeżewska A., Buszewski B. (2011). 4-Chloroanilina - metoda oznaczania. [4-Chloro-o-toluidine - determination method]. Podst. Metod. Ocen. Środ. Pr. 1(67), 67-72.

Kilanowicz A., Stragierowicz J., Skrzypińska-Gawrysiak M. (2020). 4-Chloro-2-toliloamina i jej chlorowodorek (w przeliczeniu na 4-chloro-2-toliloaminę) - frakcja wdychalna. Dokumentacja proponowanych wartości dopuszczalnych wielkości narażenia zawodowego [4-Chloro-o-toluidine and its hydrochloride - inhalable fraction. Documentation of proposed values of occupational exposure limits (OELs)]. Podst. Metod. Ocen. Środ. Pr. 3(105), 5-35.

Narvekar M.S., Srivastava A.K. (2002). Separation of banned amine isomers in relation to german ban on azo dyes by derivatization on GC-MS. Chromatographia 55, 729-735.

NIOSH, National Institute for Occupational Safety Health (1994). Manual of analytical methods. Amines aromatic. Method 2002. Fourth Edition NIOSH \#2002 [https://www.cdc. gov/niosh/docs/2003-154/pdfs/2002.pdf].

OSHA, Occupational Safety and Health Administration (1988). Sampling and analytical methods organic method \#73. $o$-Toluidine, $m$-Toluidine, $p$-Toluidine [https://www. osha.gov/dts/sltc/methods/organic/org073/org073.html].
Otero P., Kumar Saha S., Hussein A., Barron J., Murray P. (2017). Simultaneous determination of 23 azo dyes in paprika byg chromatography-mass spectrometry. Food Anal. Methods 10, 876-884.

PubChem, National Library of Medicine (2020). Compound summary 4-chloro-2-methylaniline [https://pubchem.ncbi. nlm.nih.gov/source/hsdb/2061].

Riffelmann M., Muller G., Schmieding W., Popp W., Norpoth K. (1995). Biomonitoring of urinary aromatic amines and arylamine hemoglobin adducts in exposed workers and nonexposed control persons. Int. Arch. Occup. Environ. Health 68, $36-43$.

Rozporządzenie Ministra Pracy, Rozwoju i Technologii zmieniające rozporządzenie $\mathrm{w}$ sprawie najwyższych dopuszczalnych stężeń i natężeń czynników szkodliwych dla zdrowia w środowisku pracy. DzU 2021, poz. 325 [Polish legal act].

Rozporządzenie Parlamentu Europejskiego i Rady (WE) nr 1907/2006 z dnia 18.12.2006 r. w sprawie rejestracji, oceny, udzielania zezwoleń i stosowanych ograniczeń w zakresie chemikaliów (REACH), utworzenia Europejskiej Agencji Chemikaliów, zmieniającego dyrektywę 1999/45/WE oraz uchylającego rozporządzenie Rady (EWG) nr 793/93 i rozporządzenie Komisji (WE) nr 1488/94, jak również dyrektywę Rady 76/769/EWG i dyrektywy Komisji (91/155/ EWG, 93/67/EWG, 93/105/WE i 2000/21/WE). Dz. Urz. UE z dnia 29.05.2007 r. (L 136) z późn. zm. [Regulation (EC) No $1907 / 2006$ of the European Parliament and of the Council of 18 December 2006 concerning the Registration, Evaluation, Authorisation and Restriction of Chemicals (REACH), establishing a European Chemicals Agency, amending Directive 1999/45/EC and repealing Council Regulation (EEC) No 793/93 and Commission Regulation (EC) No 1488/94 as well as Council Directive 76/769/EEC and Commission Directives 91/155/EEC, 93/67/EEC, 93/105/EC and 2000/21/EC. OJEU L 136 as amended].

Rozporządzenie Parlamentu Europejskiego i Rady WE nr 1272/2008 z dnia 16 grudnia 2008 r. w sprawie klasyfikacji, oznakowania i pakowania substancji oraz mieszanin, zmieniającego i uchylającego dyrektywy 67/548/EWG i 1999/45/ WE oraz zmieniającego rozporządzenie WE nr 1907/2006 z dnia 31.12.2008 r. Dz. Urz. WE L 353, 1-1355 z późn. zm. [Regulation (EC) No 1272/2008 of the European Parliament and of the Council of 16 December 2008 on classification, labelling and packaging of substances and mixtures, amending and repealing Directives 67/548/EEC and 1999/45/EC, and amending Regulation (EC) No 1907/2006. OJEU L 353, $1-1355$ as amended].

Wollseifen H.R. (2019). Determination of aromatic amines from azo colorants according to DIN EN ISO 17234-1. LCtech, application note AN0029 [https://www.lctech. de/fileadmin/user_upload/Applikationsnoten/LCTech/ AN0029-LCTech-eng-Application_Note-Azo-dyes.pdf ]. 


\section{PROCEDURA ANALITYCZNA \\ OZNACZANIA 4-CHLORO-2-TOLILOAMINY W POWIETRZU NA STANOWISKACH PRACY Z ZASTOSOWANIEM WYSOKOSPRAWNEJ CHROMATOGRAFII CIECZOWEJ Z DETEKCJĄ SPEKTROFOTOMETRYCZNĄ}

\section{Zakres stosowania metody}

W niniejszej procedurze podano metodę oznaczania 4-chloro-2-toliloaminy (CAS 95-69-2) w powietrzu na stanowiskach pracy $\mathrm{z}$ zastosowaniem wysokosprawnej chromatografii cieczowej $\mathrm{z}$ detekcją spektrofotometryczną (UV-VIS).

Najmniejsze stężenie 4-chloro-2-toliloaminy, jakie można oznaczyć w warunkach pobierania próbek powietrza i wykonania oznaczania opisanych w procedurze, wynosi $0,002 \mathrm{mg} / \mathrm{m}^{3}$ dla próbki powietrza o objętości 2001.

\section{Powołania normatywne}

PN-Z-04008-7 Ochrona czystości powietrza - Pobieranie próbek - Zasady pobierania próbek powietrza w środowisku pracy i interpretacji wyników.

\section{Zasada metody}

Metoda polega na: zatrzymaniu obecnej w badanym powietrzu 4-chloro-2-toliloaminy na próbniku składającym się z filtra $\mathrm{z}$ włókna szklanego (nasączonego roztworem kwasu solnego) i rurki sorpcyjnej wypełnionej żelem krzemionkowym (pokrytym kwasem solnym), wymyciu zatrzymanej na filtrze i żelu 4-chloro-2-toliloaminy metanolem i analizie chromatograficznej otrzymanego roztworu.

\section{Wytyczne ogólne}

4.1. Czystość odczynników

Do wykonania analizy, o ile nie zaznaczono inaczej, należy stosować odczynniki i substancje wzorcowe o stopniu czystości co najmniej cz.d.a.

4.2. Dokładność ważenia

$O$ ile nie zaznaczono inaczej, substancje stosowane $\mathrm{w}$ analizie należy ważyć $\mathrm{z}$ dokładnością do $0,0002 \mathrm{~g}$.

\subsection{Postępowanie $\mathrm{z}$ substancjami} niebezpiecznymi

Wszystkie czynności, podczas których używa się rozpuszczalników organicznych, należy wykonywać pod sprawnie działającym wyciągiem laboratoryjnym.

Zużyte roztwory i odczynniki należy gromadzić w przeznaczonych do tego celu pojemnikach i przekazywać do zakładów zajmujących się utylizacją.

\section{Odczynniki, roztwory i materiały}

5.1. 4-Chloro-2-toliloamina

5.2. Metanol

Stosować metanol o czystości do HPLC.

5.3. Woda

Stosować wodę destylowaną o czystości do HPLC, zwaną w dalszej części procedury wodą.

5.4. Kwas solny 38-procentowy

5.5. Roztwór wzorcowy podstawowy 4-chloro-2-toliloaminy

Do kolby pomiarowej o pojemności $5 \mathrm{ml}$ wg punktu 6.6. odważyć na wadze analitycznej ok. $5 \mathrm{mg}$ wg punktu 6.9. 4-chloro-2-toliloaminy wg punktu 5.1., kolbę uzupełnić do kreski metanolem wg punktu 5.2. i dokładnie wymieszać. Obliczyć dokładną zawartość 4-chloro-2-toliloaminy w $1 \mathrm{ml}$ roztworu.

Roztwór przechowywany w chłodziarce zachowuje trwałość przez $60 \mathrm{dni}$.

5.6. Roztwór wzorcowy pośredni 4-chloro-2-toliloaminy

Do kolby pomiarowej o pojemności $5 \mathrm{ml}$ wg punktu 6.6. odmierzyć za pomocą pipety wg punktu 6.5. taką ilość wzorca podstawowego 4-chloro-2-toliloaminy wg punktu 5.5., aby stężenie w $1 \mathrm{ml}$ roztworu wynosiło $800 \mu \mathrm{g}$.

5.7. Roztwory wzorcowe robocze 4-chloro-2-toliloaminy 
Do ośmiu kolb pomiarowych o pojemności $1 \mathrm{ml}$ wg punktu 6.6. odmierzyć za pomocą pipety wg punktu 6.5. odpowiednio: $0 ; 0,05 ; 0,1 ; 0,125 ; 0,250$; 0,5; $0,75 \mathrm{i} 1 \mathrm{ml}$ roztworu wzorcowego pośredniego wg punktu 5.6. Kolby uzupełnić do kreski metanolem wg punktu 5.2. Stężenia w tak przygotowanych roztworach wynoszą: $0 ; 40 ; 80 ; 100 ; 200$; $400 ; 600$ i $800 \mu \mathrm{g} / \mathrm{ml}$.

\subsection{Roztwór kwasu solnego}

Do kolby pomiarowej o pojemności $250 \mathrm{ml}$ wg punktu 6.6. odmierzyć $150 \mathrm{ml}$ metanolu wg punktu 5.2. i dodać $4,14 \mathrm{ml}$ kwasu solnego wg punktu 5.4. Kolbę uzupełnić do kreski metanolem. Stężenie kwasu solnego $\mathrm{w}$ tak przygotowanym roztworze wynosi $0,2 \mathrm{~mol} / \mathrm{l}$.

5.9. Filtry z włókna szklanego o średnicy $25 \mathrm{~mm}$ $\mathrm{Na}$ filtry nanieść za pomocą pipety automatycznej po $0,2 \mathrm{ml}$ roztworu kwasu solnego wg punktu 5.8. Po odparowaniu rozpuszczalnika filtry umieścić w szczelnie zamykanym pojemniku.

5.10. Filtry strzykawkowe

Stosować filtry strzykawkowe o średnicy $13 \mathrm{~mm}$ $\mathrm{z}$ membraną z PTFE o średnicy porów $0,45 \mu \mathrm{m}$.

5.11. Żel krzemionkowy

Stosować żel krzemionkowy o uziarnieniu $200 \div$ $500 \mu \mathrm{m}$, pokryty roztworem kwasu solnego.

Żel krzemionkowy przesypać do kolby okrągłodennej wg punktu 6.7., dodać roztwór kwasu solnego wg punktu 5.8. w takiej ilości, aby całkowicie przykryć żel, i pozostawić na 24 godziny. Metanolowy roztwór kwasu solnego odparować za pomocą wyparki próżniowej wg punktu 6.10. Wysuszony żel przechowywać w szczelnie zamkniętym pojemniku.

5.12. Rurki sorpcyjne o średnicy wewnętrznej $10 \mathrm{~mm}$

Przygotować próbniki do pobierania próbek powietrza wypełnione dwoma warstwami żelu krzemionkowego pokrytego kwasem solnym (150 mg/75 mg) wg punktu 5.11. Dopuszcza się stosowanie rurek sorpcyjnych dostępnych w handlu.

\section{Przyrządy pomiarowe i sprzęt pomocniczy}

\subsection{Chromatograf cieczowy}

Stosować chromatograf cieczowy $\mathrm{z}$ detektorem spektrofotometrycznym umożliwiającym wykonanie analiz o długości fali $(\lambda) 240 \mathrm{~nm}$.

6.2. Kolumna chromatograficzna

Stosować kolumnę chromatograficzną umożliwiającą oznaczanie 4-chloro-2-toliloaminy w obecności innych substancji występujących jednocześnie $\mathrm{w}$ badanym powietrzu, np. kolumna wypełniona żelem krzemionkowym modyfikowanym grupą oktadecylową o uziarnieniu $5 \mu \mathrm{m}$, o długości $150 \mathrm{~mm}$ i średnicy wewnętrznej 2,1 $\mathrm{mm}$.

6.3. Pompa ssąca

Stosować pompę ssącą umożliwiającą pobranie powietrza ze stałym strumieniem objętości wg punktu 7.

6.4. Głowice do pobierania próbek powietrza Stosować głowice umożliwiające wyodrębnienie frakcji wdychalnej.

6.5. Pipety do cieczy

Stosować pipety automatyczne nastawne o pojemności: $0,010 \div 0,1 ; 0,1 \div 1$ i $0,5 \div 5 \mathrm{ml}$.

6.6. Kolby pomiarowe

Stosować kolby pomiarowe o pojemności: 1; 5 i $250 \mathrm{ml}$.

6.7. Kolba okrągłodenna

Stosować kolbę okrągłodenną o pojemności $500 \mathrm{ml}$. 6.8. Naczynka szklane

Stosować szczelnie zamykane naczynka szklane o pojemności 2 i $4 \mathrm{ml}$.

6.9. Waga

Stosować wagę analityczną umożliwiającą ważenie $\mathrm{z}$ dokładnością do $0,0002 \mathrm{~g}$.

6.10. Wyparka próżniowa

6.11. Mieszadło rolkowe

\section{Pobieranie próbek powietrza}

Podczas pobierania próbek powietrza należy stosować zasady zawarte $\mathrm{w}$ normie PN-Z-04008-7. Za pomocą zestawu do pobierania próbek powietrza składającego się z pompy ssącej wg punktu 6.3., filtra $\mathrm{z}$ włókna szklanego wg punktu 5.9. umieszczonego $\mathrm{w}$ głowicy do pobierania próbek powietrza wg punktu 6.4. oraz rurki sorpcyjnej wg punktu 5.12. przepuścić nie mniej niż $200 \mathrm{l}$ powietrza ze stałym strumieniem objętości $2 \mathrm{l} / \mathrm{min}$. Pobrane próbki powietrza zabezpieczyć i do czasu analizy przechowywać w chłodziarce.

Pobrane próbki przechowywane w chłodziarce zachowują trwałość co najmniej $20 \mathrm{dni}$.

\section{Warunki pracy chromatografu}

Warunki pracy chromatografu należy dobrać tak, aby uzyskać rozdzielenie 4-chloro-2-toliloaminy od innych substancji występujących jednocześnie $\mathrm{w}$ badanym powietrzu. Przykładowe warunki pracy chromatografu przedstawiono w tabeli 1. 
Tabela 1. Warunki pracy chromatografu cieczowego z detektorem UV-VIS

Table 1. Classification and labeling of 4-chloro-o-toluidine in accordance with applicable legal acts

\begin{tabular}{|l|lc|c|}
\hline \multicolumn{4}{|c|}{ Kolumna analityczna Supelco Discovery C-18 $150 \times 2,1 \mathrm{~mm}, 5 \mu \mathrm{m}$} \\
\hline Faza ruchoma & Woda A & $80 \%$ & Metanol B \\
Program - gradient $(v: v)$ & $0 \mathrm{~min}$ & $80 \%$ & $20 \%$ \\
& $1 \mathrm{~min}$ & $20 \%$ & $80 \%$ \\
& $6 \mathrm{~min}$ & $80 \%$ & $20 \%$ \\
& $7 \mathrm{~min}$ & $80 \%$ & $20 \%$ \\
\hline Natężenie przepływu strumienia fazy ruchomej $0,4 \mathrm{ml} / \mathrm{min}$ & \\
\hline Temperatura kolumny & $13 \mathrm{~min}$ & \\
\hline Długość fali analitycznej & $30{ }^{\circ} \mathrm{C}$ & \\
\hline Objętość próbki & $240 \mathrm{~nm}$ \\
\hline
\end{tabular}

\section{Sporządzanie krzywej wzorcowej}

Do ośmiu naczynek szklanych o pojemności $4 \mathrm{ml}$ wg punktu 6.7. wsypać po $150 \mathrm{mg}$ żelu krzemionkowego wg punktu 5.11. i nanieść za pomocą pipety do cieczy wg punktu 6.5. po $10 \mu$ roztworów wzorcowych roboczych wg punktu 5.7. W każdym naczynku umieścić filtr $\mathrm{z}$ włókna szklanego wg punktu 5.9. Po odparowaniu rozpuszczalnika dodać po $2 \mathrm{ml}$ metanolu wg punktu 5.2. i poddać 30-minutowej ekstrakcji za pomocą mieszadła rolkowego wg punktu 6.10. Ekstrakt przepuścić za pomocą filtrów strzykawkowych wg punktu 5.10. do naczynek o pojemności $2 \mathrm{ml}$ wg punktu 6.7. Zawartość 4-chloro-2-toliloaminy w $1 \mathrm{ml} \mathrm{roz-}$ tworu wynosi odpowiednio: $0 ; 0,2 ; 0,4 ; 0,5 ; 1 ; 2 ; 3$ i $4 \mu \mathrm{g}$. Uzyskane ekstrakty poddać analizie chromatograficznej w warunkach podanych w punkcie 8 .

Sporządzić krzywą wzorcową, odkładając na osi odciętych ilość 4-chloro-2-toliloaminy naniesionej na żel, a na osi rzędnych - wartość pola powierzchni piku badanego związku. Dopuszcza się automatyczne integrowanie danych i sporządzanie krzywej wzorcowej.

\section{Wykonanie oznaczania}

Po pobraniu próbek powietrza filtry wraz $\mathrm{z}$ żelem krzemionkowym $\mathrm{z}$ dłuższej warstwy rurki sorpcyjnej przenieść do naczynek szklanych o pojemności $4 \mathrm{ml} \mathrm{wg}$ punktu 6.7. W drugim naczynku umieścić żel krzemionkowy z krótszej warstwy rurki. Do próbek dodać po $2 \mathrm{ml}$ metanolu i ekstrahować przez 30 minut za pomocą mieszadła rolkowego wg punktu 6.11. Ekstrakt przesączyć do naczynek o pojemności $2 \mathrm{ml}$ wg punktu
6.7. za pomocą filtrów strzykawkowych wg punktu 5.10. Próbki poddać analizie chromatograficznej. W przypadku próbek, których wartości pól powierzchni analizowanych pików przekraczają zakres roboczy metody, należy wykonać powtórne oznaczenie, rozcieńczając dodatkowo próbkę. Dodatkowe rozcieńczenie uwzględnić w obliczeniach.

\section{Obliczanie wyniku oznaczania}

Stężenie 4-chloro-2-toliloaminy $(X)$ w badanym powietrzu obliczyć $\mathrm{w}$ miligramach na metr sześcienny na podstawie wzoru:

$$
X=\frac{m}{V} \cdot 2,
$$

w którym:
$m$ - masa 4-chloro-2-toliloaminy odczytana z krzywej wzorcowej, w mikrogramach,
$V$ - objętość przepuszczonego powietrza przez próbniki, w litrach,
2 - współczynnik rozcieńczenia próbki. 
